\title{
Geochemical characteristics of agricultural soils, Assiut governorate, Egypt
}

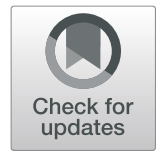

\author{
E. A. Abou El-Anwar ' (D, H. S. Mekky, W. Abdel Wahab, A. S. Asmoay, A. A. Elnazer and S. A. Salman
}

\begin{abstract}
Background: The geochemical investigation of agricultural soil is a great demand because of its help in the characterization of soil and its suitability for cultivation. The urbanization, cultivation, and industrial activities at Assiut Governorate have adversely impacted the chemical composition of soil, especially its content of heavy metals. The study area includes El-Madabgh sewage station and many big industries; cement, fertilizers, and pharmaceutical.
\end{abstract}

Results: The Nile Valley soils are very comparable in composition and composed mainly of $\mathrm{SiO}_{2}, \mathrm{Al}_{2} \mathrm{O}_{3}, \mathrm{Fe}_{2} \mathrm{O}_{3}, \mathrm{CaO}$, $\mathrm{MgO}$, and $\mathrm{TiO}_{2}$ which represent about $88 \%$ of its chemical composition. The chemical composition gave an indication about the mineralogical assemblage of soil; quartz, clay minerals, and calcite. The results pointed to the mixed source (geogenic and anthropogenic) of $\mathrm{Fe}, \mathrm{Co}, \mathrm{Cu}, \mathrm{Ni}, \mathrm{Zn}, \mathrm{Zr}$, and $\mathrm{Cr}$ and the anthropogenic source of $\mathrm{As}$, $\mathrm{Pb}$, and $\mathrm{Cd}$ (especially phosphatic fertilizers) in the studied soil.

Conclusion: The studied soil chemistry affected mainly by the agricultural practices (application of fertilizers, pesticides, manure, and wastewater irrigation), industrial inputs, and atmospheric deposition. Generally, the Egyptian soil needs more geochemical studies to monitor its quality and enhance of its productivity.

Keywords: Geochemistry, Anthropogenic activities, Heavy metals, Pollution

\section{Introduction}

Soil is a complex heterogeneous mixture of organic and inorganic matter, as well as different components that determine its physical, chemical, and biological properties. There are 12 major and minor elements $(\mathrm{Si}, \mathrm{Al}, \mathrm{O}$, $\mathrm{Ca}, \mathrm{Fe}, \mathrm{K}, \mathrm{Ti}, \mathrm{Mg}, \mathrm{Mn}, \mathrm{Na}, \mathrm{Cr}, \mathrm{Ni}$ ) representing about $99.4 \%$ of its total composition and at least 68 trace elements account for the rest. However, local or regional geochemistry plays an important role in the soil composition (Galinha et al. 2010). The major elements generally occur in minerals, so can be used as a tool of discriminating element-mineral associations (Liu et al. 2001 and Salman 2008). The Al, K, Na, and Mg elements are expected to be dominantly contained in Al-silicates such as various clay minerals, chlorite, micas, and feldspars, whereas the other elements can occur in non-Al-bearing mineral phases (Salman 2013).

Soil chemical composition is controlled mainly by lithogenic and pedogenic weathering. The Egyptian soil

\footnotetext{
* Correspondence: abouelanwar2004@yahoo.com

Geological Sciences Department, National Research Centre, 33 El Bohouth St. (former El Tahrir St.)- Dokki, Giza 12622, Egypt
}

chemistry is mainly related to the chemistry of parent rocks (mafic/ultramafic rocks) in the Ethiopian highlands. The Nile Valley sediments contains about 53.4\%, $16.5 \%, 11.8 \%, 3.7 \%, 2.5 \%, 1.1 \%, 121 \mathrm{ppm}, 152 \mathrm{ppm}$, $114 \mathrm{ppm}$, and 178 ppm of $\mathrm{SiO}_{2}, \mathrm{Al}_{2} \mathrm{O} 3, \mathrm{Fe}_{2} \mathrm{O}_{3}, \mathrm{CaO}$, $\mathrm{MgO}, \mathrm{TiO}_{2}, \mathrm{Cr}, \mathrm{Ni}, \mathrm{Cu}$, and $\mathrm{Zn}$, respectively (Omer 1996). Iron (Fe) content in alluvial soils at El-Saff reached $16.6 \%$ in the surface deposit which irrigated with liquid industrial wastes (Rabie and Abd El-Sabour 1999) and $\mathrm{Ni}$ recorded $55.3 \mathrm{ppm}$ in alluvial soils at El-Fayoum (El-Sayed and Hegazy 1993). Mohamed et al. (2013) pointed out the overload of dust fall with about 3.30, 26.46, 22.33, 235.00, 4.53, and $3.80 \mathrm{ppm}$ of $\mathrm{As}, \mathrm{Cu}$, $\mathrm{Pb}, \mathrm{Zn}, \mathrm{Cd}$, and $\mathrm{Hg}$; respectively around Assiut Fertilizer Plant. Elgharably et al. (2014) stated that soils at Assiut are polluted with $\mathrm{Fe}, \mathrm{Mn}, \mathrm{Zn}, \mathrm{Cu}, \mathrm{Pb}, \mathrm{Cd}$, and $\mathrm{Ni}$ as a result of the application of sewage wastewater for irrigation.

Nowadays, pollution is considered as one of the main grave problems in the world, because the pollutants are potentially hazardous to human and animal life. The industrial practices may be causing redistribution of some hazardous elements in the environment; air, water, and 
surface soil. Some of these elements are vital, whereas others are toxic metals (Samuding et al. 2009). Thus, the industrial zones are probably the majority significant source of soil and plant contamination with heavy metals (Mohamed et al. 2015). Thus, the content and type of these metals depend on the nature of industrial activities.

Thus, the aim of this study was to assess the geochemical characters of the soil in the studied area. In addition, indicating the source of the heavy metals into the soil and try to give some recommendations to improve its nature.

\section{Materials and methods}

\section{The study area}

Assiut is located between latitudes $26^{\circ} 50^{\prime}$ and $27^{\circ} 40^{\prime} \mathrm{N}$ and longitudes $30^{\circ} 40^{\prime}$ and $31^{\circ} 32^{\prime} \mathrm{E}$ which borders at the River Nile on both eastern and western sides and the cultivated soil extends along the two banks of the Nile Valley (Fig. 1). It comprises part of the Nile Valley and parts of the surrounding plateaus. Assiut Governorate contains many big industries, such as cement chemical, fertilizers, detergents, and food. The study area includes mainly the relative wide stretch extending to the west of the Nile River.

Many authors studied the geology (Fig. 2) and structural geology of the area (Said 1962; Said 1981; Omer 1996; Osman 1980; Khalifa et al. 2004). The area of study is distinguished into the following three main geomorphic units:

- The young alluvial plain (Holocene silty clay): it represents the cultivated lands bordering the western side of the Nile. It is dissected by irrigation canals and drains running from south to north parallel to the River Nile. The cultivated lands to the west of the River Nile in Assiut are generally much wider than those lands to the east.

- The old alluvial plain (Quaternary sand and gravel): it is represented by terraces with various elevations between the calcareous plateau and the young alluvial plain. It contains some elongated sand dunes which cover the eastern areas of the scarp of the carbonate plateau. It takes mainly the northwest-

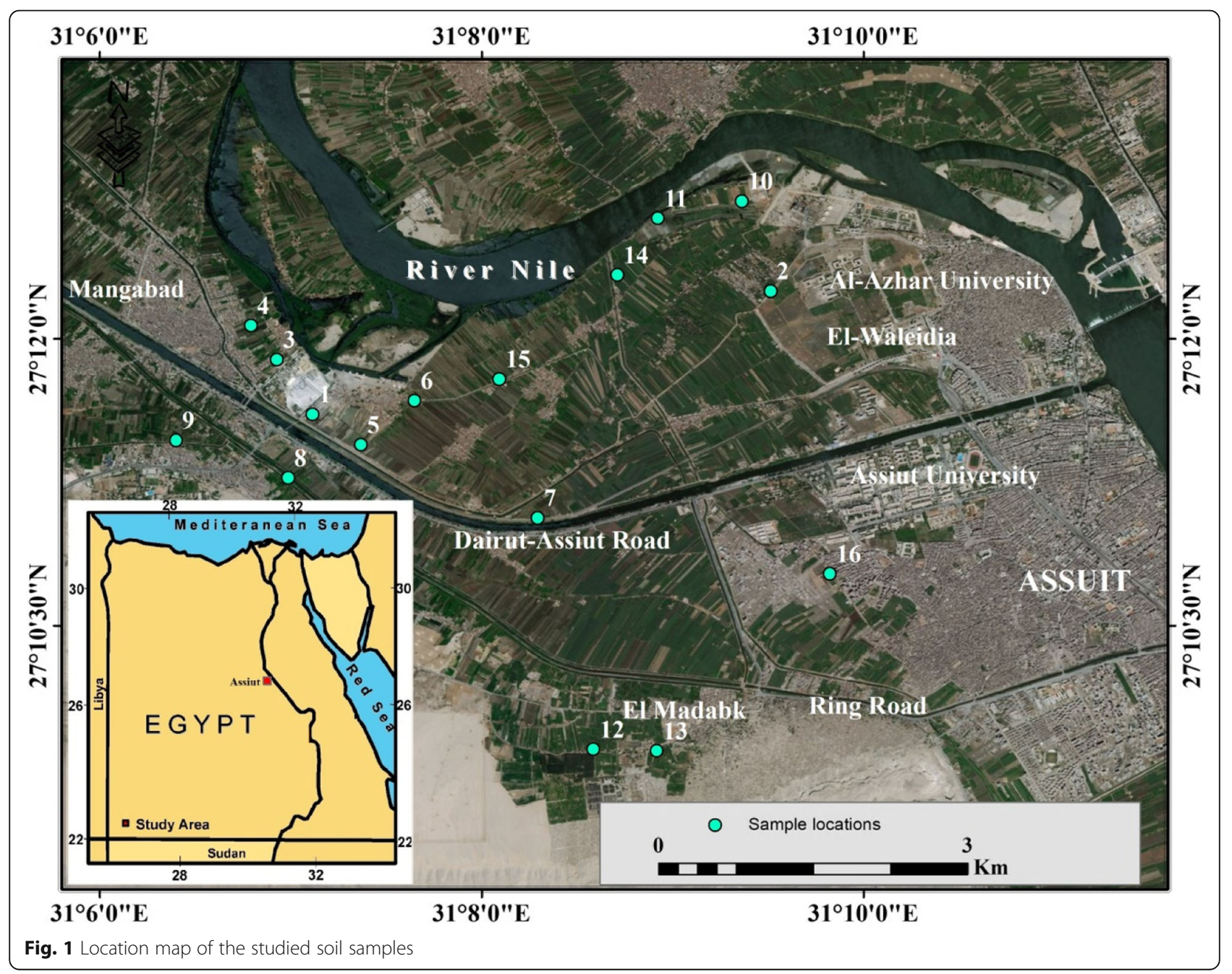




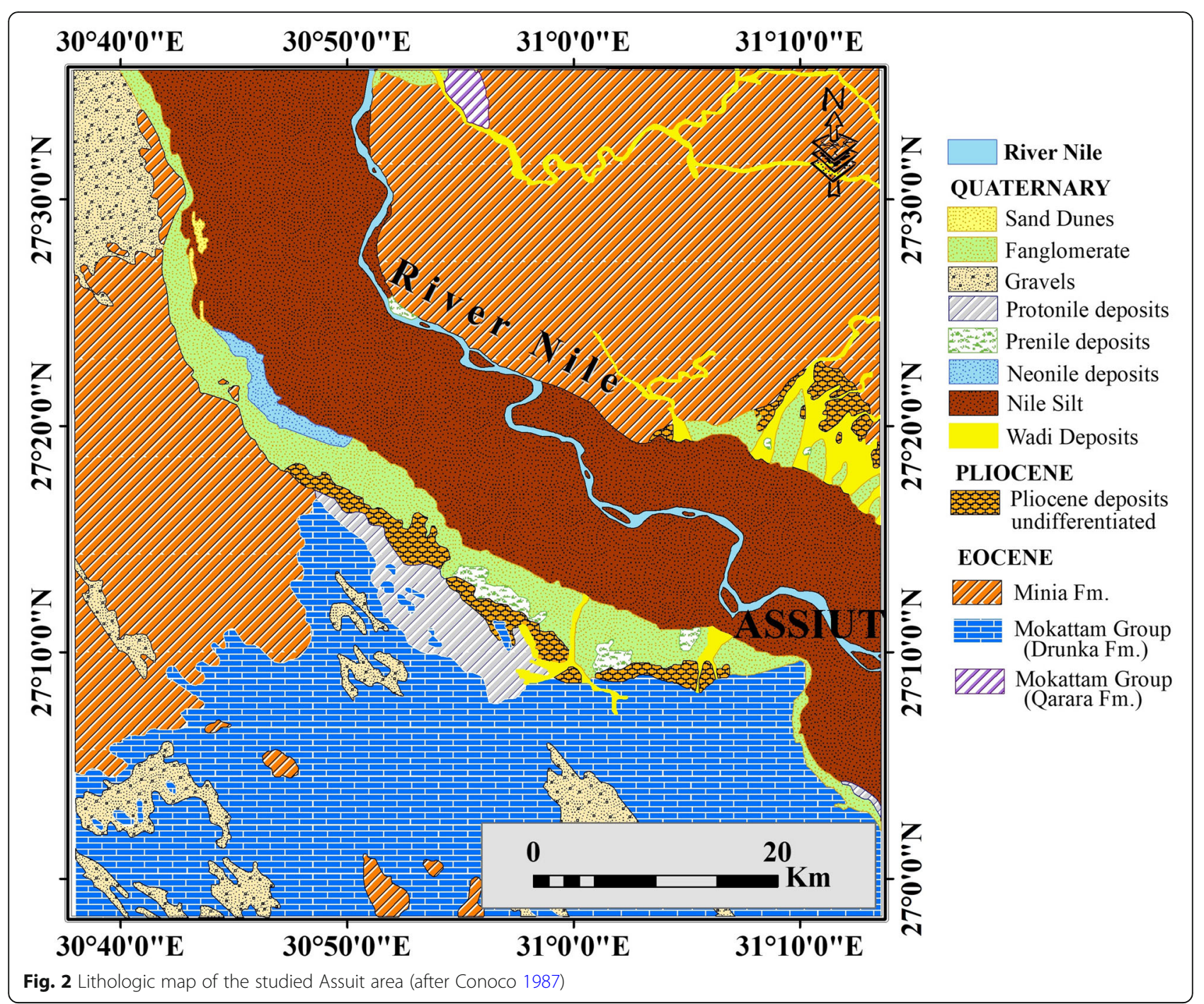

southeast direction and threats the cultivated lands of the alluvial plains. The old terraces cover a considerable area and formed mainly of travertine conglomerate with gravel, sandstone, and clay.

- The calcareous plateau: The eastern slope of the western calcareous plateau in the area of study represents the eastern fringes of the Nile Valley. It has an elevation higher than floodplain varies from south to the north respectively. It is built of Eocene limestone covered by drift sands, flints, and the boulder of carbonate. The surface is formed into gravelly plains of black to dark brown color occupying areas of the surface.

\section{Sampling and analyses}

Sixteen soil samples (30 cm depth) were collected around the industrial activities in the study area, which is represented the young alluvial plain. The XRF analysis was used to determine the main and trace elements in the studied soils in order to reveal the geogentic and anthropogenic enrichments of elements nearby the industrial activities.

The XRF analysis was made by using Axios Sequential WD_XRF Spectrometer, Analytical 2005 in the National Research Center laboratories. ASTM E1621 standard guide was used for elemental analysis by wavelength dispersive X-ray fluorescence spectrometer and ASTM D7348 standard test methods for loss on ignition (LOI) of solid combustion. The samples were ground to $<63 \mu \mathrm{m}$ in diameter.

\section{Results}

Generally, the Nile Valley soils are very comparable in composition, since they are created from the same sources of weathered sedimentary and magmatic rocks. However, resulting of the anthropogenic input, the percentage of exact trace elements can change obviously depending on the land utilize (cultivated, urban, or industrial). 
The average concentration of the major oxides (wt\%) in the studied soils are 50.06, 13.58, 12.01, 6.44, 2.65, 1.83, 1.3, 0.82, 0.69, 0.52, and 0.09 for $\mathrm{SiO}_{2}, \mathrm{Al}_{2} \mathrm{O}_{3}$, $\mathrm{Fe}_{2} \mathrm{O}_{3}, \mathrm{CaO}, \mathrm{MgO}, \mathrm{TiO}_{2}, \mathrm{~K}_{2} \mathrm{O}, \mathrm{Na}_{2} \mathrm{O}, \mathrm{P}_{2} \mathrm{O}_{5}, \mathrm{SO}_{3}$, and $\mathrm{Cl}$; respectively, as well as LOI $=9.55$ (Table 1 ). The average levels of trace elements in the studied area are as follows in decreasing order: $\mathrm{Mn}, \mathrm{Zr}, \mathrm{Zn}, \mathrm{Cr}, \mathrm{Ni}, \mathrm{Pb}, \mathrm{Co}, \mathrm{Cu}, \mathrm{As}$, and $\mathrm{Cd}$ are $\sim 1181, \sim 266, \sim 119, \sim 117, \sim 84, \sim 38, \sim 35$, $\sim 32,15.41$, and $1.37 \mathrm{ppm}$, respectively (Table 2).

\section{Discussion}

\section{The major elements}

The major element oxides generally occur in minerals. Thus, major oxides analysis is useful as a tool for discriminating element-mineral associations (Liu et al. 2001 and Salman 2008). Abou El-Anwar et al. (2018) stated that Assiut soil is composed mainly of quartz, anorthite, calcined albite, calcite, montmorillonite, vermiculite, and illite mineral assemblages. Melegy and El-Agami (2004) stated that the mineralogical composition of soil at Bahtim, Egypt is mainly quartz, plagioclase, amphibole, smectite, kaolinite, and illite. Also, Salman (2013) mentioned that Sohag soils are mainly composed of quartz, feldspars, calcite, montmorillonite, and kaolinite. $\mathrm{Al}, \mathrm{K}, \mathrm{Na}$, and $\mathrm{Mg}$ elements are expected to be dominantly contained in Al-silicate minerals; clay minerals, chlorite, micas, and feldspars, while the other elements can also occur in the non-silicate mineral phases (Van der Veer 2006).

$\mathrm{High} \mathrm{SiO}_{2}$ content in the studied soils is possibly due to the abundance of quartz (Hussein et al. 2004 and Salman 2008) in agreement with the mineralogical studied for the same studied samples with Abou El-Anwar et al. (2018). This is supported by the strong significant positive correlation between $\mathrm{SiO}_{2}$ and sand content $(r=0.77)$ as well as negative correlation $(-0.81)$ between $\mathrm{SiO}_{2}$ and $\mathrm{Al}_{2} \mathrm{O}_{3}$ (Table 3).

To further investigate the role of Al-minerals for the distribution of different major elements, a simple linear regression analysis was performed (Table 3). The results of this regression indicate that the concentrations of $\mathrm{K}$, $\mathrm{Fe}, \mathrm{Ti}$, and $\mathrm{Mg}$ are primarily related to $\mathrm{Al}$, and as such, these elements are dominantly controlled by clay minerals and/or by minerals associated with clays during sedimentation. Sample No. 10 recorded the highest percentages of $\mathrm{Al}_{2} \mathrm{O}_{3}, \mathrm{Fe}_{2} \mathrm{O}_{3}$, and $\mathrm{TiO}_{2}(16.26,15.51$, and $2.48 \%$; respectively Table 1 ) which referred to the abundance of vermiculite mineral, its agreements with the mineralogical studies Abou El-Anwar et al. (2018).

Iron $\left(\mathrm{Fe}_{2} \mathrm{O}_{3}\right)$ content ranges from 4.58 to $15.52 \%$ and averages $12.01 \%$, which is strongly higher than that of the values UUC (5.04\%) recorded by Rudnick and Gao (2014). Thus, the enrichment of iron in the studied soils may be strongly controlled by the source rock composition, where they are derived principally from the Ethiopian basaltic plateau (Omer 1996; Abou El-Anwar and Samy 2013; Abou El-Anwar et al. 2018). $\mathrm{Fe}_{2} \mathrm{O}_{3}$ is positively correlated with silt and clay content $(r=0.64$ and 0.57; respectively), and not correlated with carbonate content $(r=0.09)$. Thus, the unusually high concentration of $\mathrm{Fe}_{2} \mathrm{O}_{3}$ recorded in most samples might be attributed to effluents from Seed Pharmaceutical, Mangabad factories, sewage station in the studied area.

Table 1 Major oxides contents and LOI in the studied soil samples (\%)

\begin{tabular}{|c|c|c|c|c|c|c|c|c|c|c|c|c|c|c|c|c|c|}
\hline SN & Sand & Silt & Clay & $\mathrm{CaCO}_{3} \%$ & $\mathrm{CaSO}_{4} \%$ & $\mathrm{SiO}_{2}$ & $\mathrm{Al}_{2} \mathrm{O}_{3}$ & $\mathrm{Fe}_{2} \mathrm{O}_{3}$ & $\mathrm{CaO}$ & $\mathrm{MgO}$ & $\mathrm{TiO}_{2}$ & $\mathrm{~K}_{2} \mathrm{O}$ & $\mathrm{Na}_{2} \mathrm{O}$ & $\mathrm{P}_{2} \mathrm{O}_{5}$ & $\mathrm{SO}_{3}$ & $\mathrm{Cl}$ & LOI \\
\hline 1 & 22.5 & 43.5 & 34 & 1 & 8.8 & 44.8 & 14.2 & 13.2 & 6.6 & 2.7 & 2.0 & 1.2 & 0.9 & 2.1 & 3.5 & 0.1 & 8.3 \\
\hline 2 & 19.5 & 47.25 & 32.75 & 5 & 0.4 & 48.2 & 15.7 & 14.4 & 4.2 & 2.6 & 2.2 & 1.5 & 0.9 & 0.5 & 0.2 & 0.0 & 9.2 \\
\hline 3 & 9.75 & 61.75 & 27.5 & 7.5 & 0.4 & 44.1 & 15.0 & 13.1 & 5.1 & 3.1 & 1.9 & 1.4 & 0.8 & 0.7 & 0.2 & 0.0 & 14.1 \\
\hline 4 & 11 & 53.25 & 35 & 7 & 0.2 & 46.0 & 16.4 & 12.9 & 4.1 & 3.3 & 2.1 & 1.1 & 0.8 & 0.3 & 0.1 & 0.0 & 12.3 \\
\hline 5 & 32 & 39.25 & 27.5 & 25 & 0.2 & 46.5 & 14.5 & 14.4 & 5.8 & 2.9 & 2.3 & 1.3 & 1.0 & 0.9 & 0.2 & 0.0 & 9.6 \\
\hline 6 & 6.25 & 56 & 35 & 5 & 0.2 & 44.7 & 15.6 & 13.3 & 3.9 & 3.2 & 2.0 & 1.1 & 1.0 & 0.6 & 0.1 & 0.0 & 13.9 \\
\hline 7 & 33.48 & 32.5 & 32.5 & 5 & 0.4 & 50.1 & 14.9 & 13.6 & 4.3 & 2.8 & 1.7 & 1.6 & 0.8 & 0.4 & 0.2 & 0.0 & 9.2 \\
\hline 8 & 72.5 & 3.5 & 24 & 7.5 & 0 & 55.5 & 12.5 & 11.0 & 8.8 & 2.1 & 1.8 & 1.4 & 0.5 & 0.5 & 0.2 & 0.0 & 5.3 \\
\hline 9 & 58.88 & 21.25 & 20 & 12.5 & 0 & 56.1 & 12.3 & 10.1 & 6.1 & 2.3 & 1.6 & 1.4 & 0.6 & 1.1 & 0.3 & 0.1 & 7.7 \\
\hline 10 & 66.45 & 18.75 & 16.25 & 0.5 & 0.2 & 48.1 & 16.3 & 15.5 & 5.3 & 3.0 & 2.5 & 1.5 & 0.9 & 0.4 & 0.1 & 0.0 & 6.0 \\
\hline 11 & 46.25 & 35.25 & 19 & 34 & 0 & 50.8 & 13.6 & 12.3 & 5.7 & 3.0 & 1.9 & 1.3 & 0.9 & 0.3 & 0.3 & 0.0 & 9.3 \\
\hline 12 & 71.2 & 10 & 17.5 & 10 & 0.5 & 58.7 & 8.4 & 5.9 & 14.4 & 1.9 & 1.0 & 1.1 & 0.6 & 1.1 & 0.8 & 0.2 & 7.6 \\
\hline 13 & 82.5 & 2.75 & 16 & 0.5 & 0 & 77.1 & 7.6 & 4.6 & 2.9 & 1.0 & 0.6 & 1.1 & 0.3 & 0.8 & 0.3 & 0.0 & 3.3 \\
\hline 14 & 17.75 & 50 & 32.5 & 7.5 & 0.5 & 43.4 & 14.3 & 13.3 & 7.1 & 3.2 & 2.2 & 1.2 & 0.8 & 0.4 & 0.1 & 0.0 & 13.1 \\
\hline 15 & 60 & 16 & 24 & 6 & 1 & 48.0 & 12.3 & 11.7 & 9.1 & 2.9 & 1.7 & 1.4 & 1.3 & 0.4 & 0.9 & 0.6 & 8.3 \\
\hline 16 & 17.23 & 51.5 & 31.5 & 10 & 11.4 & 38.8 & 13.8 & 13.0 & 9.6 & 2.6 & 1.6 & 1.3 & 0.9 & 0.5 & 0.9 & 0.2 & 15.7 \\
\hline Mean & 39.2 & 33.9 & 26.6 & 9.0 & 1.5 & 50.1 & 13.6 & 12.0 & 6.4 & 2.7 & 1.8 & 1.3 & 0.8 & 0.7 & 0.5 & 0.1 & 9.5 \\
\hline
\end{tabular}


Table 2 Heavy metals (ppm) contents in the studied agriculture soil

\begin{tabular}{llllllllllll}
\hline $\mathrm{SN}$ & $\mathrm{Fe}$ & $\mathrm{Mn}$ & $\mathrm{Zn}$ & $\mathrm{Zr}$ & $\mathrm{As}$ & $\mathrm{Pb}$ & $\mathrm{Cd}$ & $\mathrm{Co}$ & $\mathrm{Cr}$ & $\mathrm{Cu}$ & $\mathrm{Ni}$ \\
\hline 1 & $29,041.3$ & 1310.8 & 134.2 & 277.4 & 20.5 & 38.5 & 2.4 & 39.9 & 154.6 & 35.4 & 92.4 \\
2 & $30,826.4$ & 1249.7 & 135.3 & 290.0 & 19.8 & 37.3 & 1.1 & 43.5 & 130.3 & 36.7 & 91.2 \\
3 & $34,023.6$ & 1753.0 & 143.2 & 300.3 & 13.4 & 38.4 & 1.2 & 48.2 & 131.5 & 45.7 & 113.9 \\
4 & $35,347.4$ & 1712.5 & 135.3 & 305.9 & 15.4 & 37.6 & 1.1 & 47.3 & 151.7 & 41.7 & 102.6 \\
5 & $28,583.8$ & 1124.2 & 117.8 & 276.4 & 4.8 & 35.0 & 1.7 & 43.6 & 136.5 & 31.2 & 91.2 \\
6 & $35,746.1$ & 1899.3 & 144.4 & 308.6 & 15.4 & 34.3 & 1.8 & 42.6 & 148.1 & 34.9 & 85.9 \\
7 & $25,148.2$ & 988.4 & 108.9 & 264.9 & 15.6 & 36.0 & 1.6 & 39.6 & 117.0 & 31.4 & 93.5 \\
8 & $10,690.4$ & 647.5 & 69.3 & 232.3 & 16.8 & 28.9 & 1.6 & 13.8 & 114.0 & 13.3 & 43.0 \\
9 & $14,277.9$ & 643.9 & 133.0 & 265.2 & 17.5 & 43.7 & 1.1 & 21.0 & 67.6 & 28.9 & 62.2 \\
10 & $20,150.1$ & 944.6 & 88.5 & 232.0 & 13.2 & 33.3 & 1.2 & 41.4 & 103.7 & 32.5 & 83.9 \\
11 & $26,990.5$ & 1297.2 & 111.9 & 288.4 & 15.3 & 32.1 & 1.7 & 35.2 & 151.0 & 34.0 & 81.8 \\
12 & 6958.4 & 331.2 & 144.6 & 212.6 & 18.4 & 55.7 & 0.8 & 14.7 & 45.3 & 23.6 & 140.3 \\
13 & 5127.5 & 238.5 & 84.4 & 101.9 & 16.7 & 30.4 & 0.4 & 11.9 & 36.6 & 12.1 & 28.3 \\
14 & $31,139.5$ & 2381.9 & 124.0 & 278.7 & 15.5 & 35.5 & 1.3 & 46.9 & 120.1 & 38.8 & 97.1 \\
15 & $16,269.6$ & 792.7 & 90.2 & 369.5 & 13.2 & 38.3 & 1.8 & 27.9 & 126.6 & 20.9 & 51.8 \\
16 & $27,070.4$ & 1573.9 & 144.4 & 254.3 & 15.2 & 59.2 & 1.3 & 48.6 & 133.3 & 44.3 & 88.1 \\
Mean & $23,586.9$ & 1180.6 & 119.3 & 266.2 & 15.4 & 38.4 & 1.4 & 35.4 & 116.7 & 31.6 & 84.2 \\
\hline
\end{tabular}

Table 3 Correlation matrix of the major oxides in the studied agricultural soils

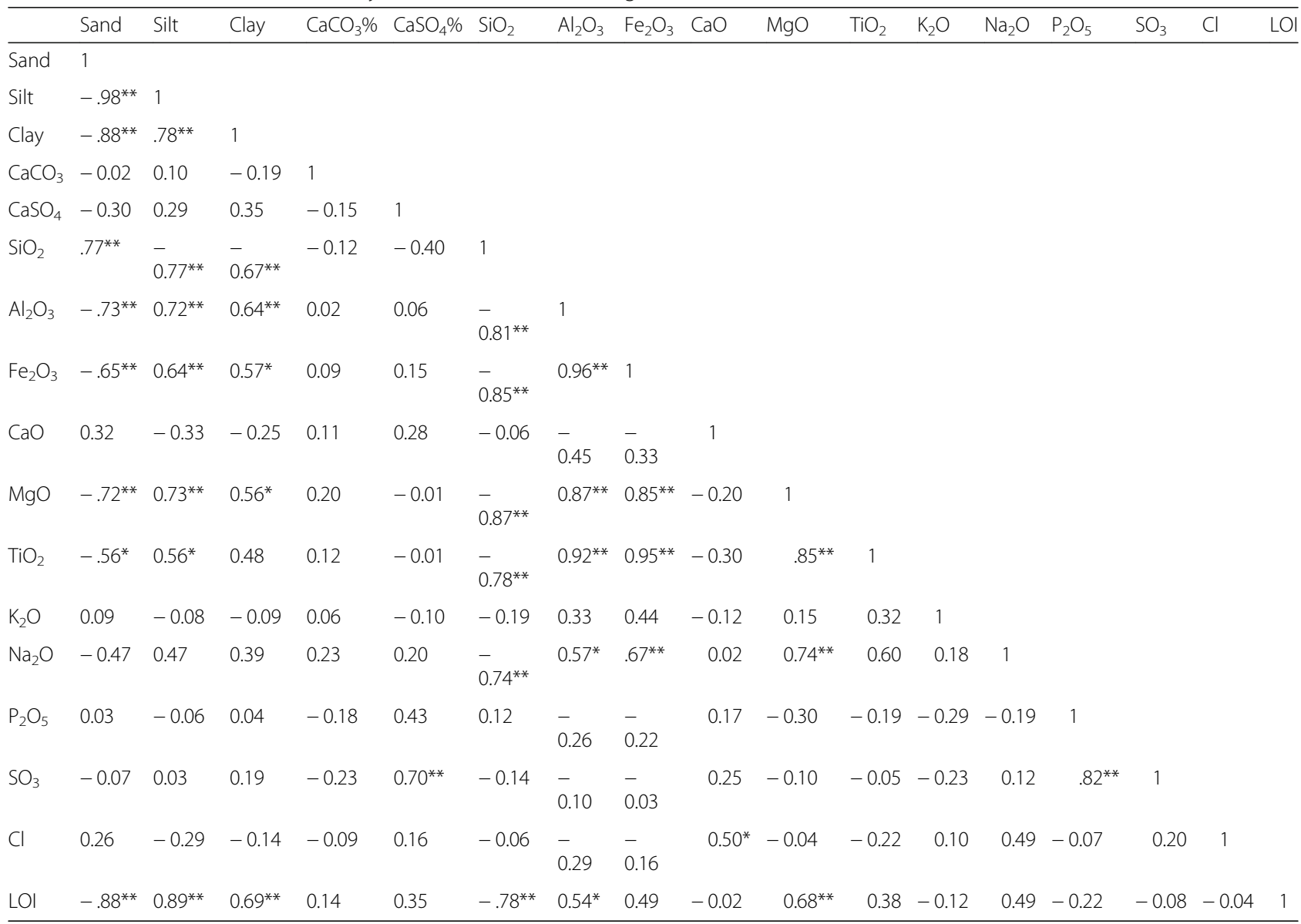


$\mathrm{Fe}_{2} \mathrm{O}_{3}$ is strongly to medium correlated with $\mathrm{Al}_{2} \mathrm{O}_{3}$, $\mathrm{TiO}_{2}, \mathrm{MgO}, \mathrm{NaO}$, and $\mathrm{K}_{2} \mathrm{O}(r=0.96,0.95,0.85,0.67$, and 0.44 ; respectively) (Table 3 ). This indicates that montmorillonite is the main bearer for $\mathrm{Fe}$ (Al-Gamal 2011; Salman 2013; Abou El-Anwar et al. 2018). The high concentration of $\mathrm{Fe}_{2} \mathrm{O}_{3}$ may be attributed to the presence of other iron-bearing phases in the soil such as ferromagnesian minerals (amphibolies and pyroxene), iron oxides (magnetite and hematite), and chlorite. Where Sohag soil contains a significant amount of chlorite (Bekir 1997). The high average percentage of iron content $(12.01 \%)$ may be reacted with the montmorillonite in suitable media and produced the vermiculite $(\mathrm{Mg}, \mathrm{Fe}$, $\mathrm{Al}$-silicate) which is in agreement with the mineralogical studied for the same studied samples with Abou El-Anwar et al. (2018). This is also supported by the positive relation between $\mathrm{MgO}$ and LOI $(r=0.68)$ (Table 3), where montmorillonite is unstable at high temperature.

Also, the higher average content of Mn ( 1181 ppm) is attributed to its high level in the parent source rocks mainly the basaltic rocks of the Ethiopian plateau, where $\mathrm{Mn}$ is substituted with iron in the ferromagnesian silicate minerals (Table 2).

The negative correlation between $\mathrm{CaO}$ and all major oxides indicates that $\mathrm{Ca}$ is present mainly in the form of carbonate minerals. High levels of calcite were identified by the XRD results (Abou El-Anwar et al. 2018) and chemical analysis (Table 1 ). The very low correlation between $\mathrm{CaO}$ and both of LOI $(r=-0.02)$ and $\mathrm{CaCO}_{3}(r=0.10)$ (Table 3) suggests other sources for $\mathrm{Ca}$ than carbonate minerals; Ca-albite (Abou El-Anwar et al. 2018).

The higher content $(1.83 \%)$ of $\mathrm{TiO}_{2}$ than the world soil $(0.55 \%)$ (Kabata-Pendias and Mukherjee 2007) point to the presence of abundance Ti-bearing minerals. The very strong positive relation between $\mathrm{TiO}_{2}$ and both of $\mathrm{Fe}_{2} \mathrm{O}_{3}(r=0.95)$ and $\mathrm{MgO}(r=0.85)$ indicated the role of ferromagnesian minerals in $\mathrm{Ti}$ distribution. Also, the strong positive relation of $\mathrm{TiO}_{2}$ with $\mathrm{Al}_{2} \mathrm{O}_{3}$, silt, and clay $(r=0.92,0.56$, and 0.48 ; respectively) indicated another source of Ti; clay minerals.

The $\mathrm{Na}_{2} \mathrm{O}$ content is positively correlated with $\mathrm{Al}_{2} \mathrm{O}_{3}$, $\mathrm{Fe}_{2} \mathrm{O}_{3}, \mathrm{MgO}$, and $\mathrm{TiO}_{2}$ with correlation coefficients of $r$ $=0.56,0.67,0.74$, and 0.60 , respectively (Table 3 ), suggesting that $\mathrm{Na}$ is mainly associated with silicate minerals (Querol et al. 1998). This result is in accordance with the mineralogical results (Abou El-Anwar et al. 2018) for the same studied samples which indicate the presence of significant amount of albite. Small amounts of $\mathrm{Na}$ can be incorporated in the crystal lattice or adsorbed on the clay mineral surfaces. As indicated from the positive relation between $\mathrm{Na}_{2} \mathrm{O}$ versus silt and clay $(r=0.47$ and 0.39 , respectively), this supports the confinement of $\mathrm{Na}$ in feldspars particles which are largely removed from the clay fraction.
Sulfur $\left(\mathrm{SO}_{3}\right)$ shows no clear relation with $\mathrm{Al}_{2} \mathrm{O}_{3}$, indicating that their occurrence is largely conquered by gypsum and/or phosphatic fertilizer, which is confirmed with the positive correlation $(r=0.70$ and 0.82 , respectively) between $\mathrm{SO}_{3}$ and both of gypsum $\left(\mathrm{CaSO}_{4}\right)$ and $\mathrm{P}_{2} \mathrm{O}_{5}$ (Table 3). Also, $\mathrm{Cl}$ has a positive relationship with $\mathrm{Na}_{2} \mathrm{O}(r=0.49$, Table 3$)$ which revealed that $\mathrm{Cl}$ may mainly come from irrigation water. $\mathrm{P}_{2} \mathrm{O}_{5}$ contents range from 0.26 to $2.11 \%$. Sample No. 1 represented the highest values of both $\mathrm{P}_{2} \mathrm{O}_{5}$ and $\mathrm{SO}_{3}(2.11$ and $3.5 \%$, respectively), where this sample is located south of Mangabad fertilizer factory.

Loss on ignition (LOI) ranges from 3.31 to $15.74 \%$ with an average of $9.55 \%$ (Table 1). The main contributors to LOI are fine particle (silt and clay) minerals. This is confirmed from the significant positive correlation between LOI versus silt, clay, $\mathrm{Al}_{2} \mathrm{O}_{3}, \mathrm{Fe}_{2} \mathrm{O}_{3}, \mathrm{MgO}, \mathrm{Na}_{2} \mathrm{O}$, and $\mathrm{TiO}_{2}(r=0.89,0.69,0.54,0.49,0.68,0.49$, and 0.38 , respectively) (Table 3 ). The higher LOI values confirm the content of montmorillonite while lower values confirm high kaolinite content, which is in agreement with Al-Gamal (2011).

Gypsum is a characteristic mineral in the soil of arid and semi-arid regions. Gypsum is a moderately soluble source of the essential nutrients for the plants (Choudhary et al. 2004). It is formed from the oxidation of pyrite in the environment rich in calcium carbonate or leaching of hillslope sediments rich in gypsum (Herrero and Porta 2000). It is one of the soluble salts that have dangerous effects on the soils, buildings, and earth structures if occurred in high quantities (Razouki and Kuttah 2006). Gypsum contents vary from null to $11.4 \%$ in the investigated soil samples (Table 1). Soils can be classified as gypsiferous soil if gypsum constitutes $>50 \%$ (Al-Marsoumi et al. 2008). It was observed that more than $69 \%$ of the studied samples contain less than $0.5 \%$ gypsum. Consequently, gypsum may be derived from the weathering of the limestone plateau in the western side of the study area.

The statistical analysis supported the control of major oxides in the mineralogical composition of the soil. Where five principal components (PCs) were extracted (Table 4 and Fig. 3). The PC1 has $43.76 \%$ of the variance and represent the role of clay minerals where $\mathrm{Al}, \mathrm{Ti}, \mathrm{Fe}, \mathrm{Na}, \mathrm{Mg}$, silt, and clay are loaded in this PC. In PC2, gypsum, $\mathrm{CaO}$, $\mathrm{P}_{2} \mathrm{O}_{5}$, and $\mathrm{SO}_{3}$ were loaded and indicated the role of used fertilizers and have $17.76 \%$ of the variance. The PC3 represented $12.6 \%$ of the variance and indicated the role of marine sediment where it loads $\mathrm{Ca}, \mathrm{Na}$, and $\mathrm{Cl}$.

\section{The trace elements}

Trace metals can be accumulated in soils as a result of human activities and consequentially affect human 
Table 4 Principal component matrix of the extracted factors controlling major oxides

\begin{tabular}{llllll}
\hline & $P C 1$ & $P C 2$ & $P C 3$ & $P C 4$ & $P C 5$ \\
\hline Sand & -0.860 & -0.209 & 0.302 & 0.251 & 0.132 \\
Silt & 0.853 & 0.158 & -0.288 & -0.284 & -0.058 \\
$\mathrm{Clay}$ & 0.750 & 0.324 & -0.292 & -0.081 & -0.298 \\
$\mathrm{CaCO}_{3}$ & 0.101 & -0.279 & 0.271 & -0.544 & 0.680 \\
$\mathrm{CaSO}_{4}$ & 0.202 & 0.811 & 0.073 & 0.089 & 0.058 \\
$\mathrm{SiO}_{2}$ & -0.917 & -0.210 & -0.248 & 0.059 & -0.026 \\
$\mathrm{Al}_{2} \mathrm{O}_{3}$ & 0.946 & -0.173 & -0.083 & 0.198 & 0.033 \\
$\mathrm{Fe}_{2} \mathrm{O}_{3}$ & 0.933 & -0.120 & 0.106 & 0.267 & 0.125 \\
$\mathrm{CaO}$ & -0.323 & 0.405 & 0.599 & -0.248 & 0.070 \\
$\mathrm{MgO}_{\mathrm{TiO}_{2}}$ & 0.920 & -0.125 & 0.165 & -0.130 & 0.012 \\
$\mathrm{~K}_{2} \mathrm{O}$ & 0.873 & -0.176 & 0.077 & 0.213 & 0.206 \\
$\mathrm{Na}_{2} \mathrm{O}$ & 0.216 & -0.401 & 0.370 & 0.636 & 0.138 \\
$\mathrm{P}_{2} \mathrm{O}_{5}$ & 0.698 & 0.108 & 0.582 & -0.102 & -0.073 \\
$\mathrm{SO}_{3}$ & -0.204 & 0.760 & -0.249 & 0.203 & 0.368 \\
$\mathrm{Cl}$ & -0.003 & 0.903 & 0.018 & 0.240 & 0.211 \\
$\%$ of variance & -0.156 & 0.265 & 0.817 & -0.018 & -0.404 \\
\hline & 43.76 & 17.76 & 12.6 & 7.5 & 6.3 \\
\hline
\end{tabular}

health. The values of maximum allowable limits (MAL) must be taken into consideration for the assessment of heavy metal pollution in soils (Ji et al. 2012).

The average concentrations of the trace elements $\mathrm{Mn}$, $\mathrm{Zr}, \mathrm{Zn}, \mathrm{Cr}, \mathrm{Ni}, \mathrm{Pb}, \mathrm{Co}, \mathrm{Cu}, \mathrm{As}$, and $\mathrm{Cd}$ are $~ 1181, \sim 266$, $\sim 119, \sim 117, \sim 84, \sim 38, \sim 35, \sim 32,15.41$, and $1.37 \mathrm{ppm}$, respectively (Table 2). The average concentrations in worldwide soil were 437, 300, 63, 54, 22, 25, 7.9, 20, 5, and $0.5 \mathrm{ppm}$, respectively (Kabata-Pendias and Mukherjee 2007). It was observed the enrichment of the studied soils with these elements than the world soil. Heavy

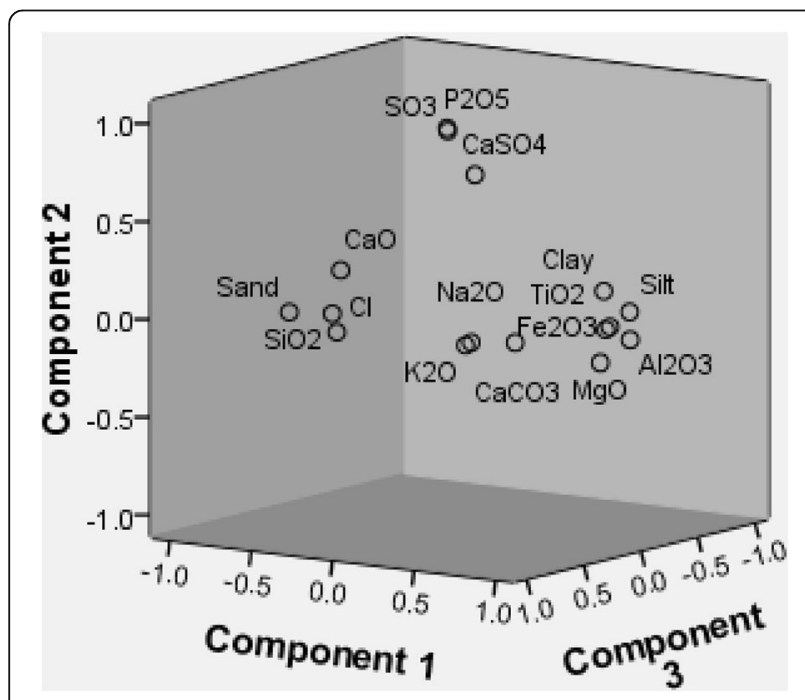

Fig. 3 Component plot in rotated space metals are one of the most soil, water, and plant pollutants (Elnazer et al. 2015; Salman et al. 2017), owing to their persistent, non-biodegradable, and toxic characteristics (Massas et al. 2009).

Contamination of agricultural soils by heavy metals may result from the use of fertilizers, chemicals, irrigation water, and dust-fall (Salman et al. 2017). This led to trace metals concentrated in foodstuff and potential hazard to human health (Lu et al. 2015). Many studies pointed out the pollution of agricultural soil heavy metals in different localities in Egypt. Darwish and Pollmann (2015) recorded 19.69, 38.17, 133.1, 47.2, and $31.69 \mathrm{ppm}$ of $\mathrm{Cd}, \mathrm{Co}, \mathrm{Cr}, \mathrm{Cu}$, and $\mathrm{Pb}$, respectively in the agricultural soil of Aswan. Also, the agricultural soil was found polluted with $\mathrm{Cd}$ in Kafr El-Sheikh, El-Fayoum, El-Mehala El-Kobra, and Kafr El-Zayat and they recorded high concentration of $\mathrm{Cd}$ (Al Naggar et al. 2014). Salman (2013) pointed out the pollution of agricultural soils at Sohag Governorate with Cd (22 ppm). On the northern part of the study area at El Minya Governorate, the agriculture soil contains about $1.19 \mathrm{ppm}$ (Asmoay 2017). The exposure to polluted soil with heavy metals has a diverse effect on human health (Karim et al. 2015). Also, polluted soil with $\mathrm{Cd}, \mathrm{Cu}, \mathrm{Cr}$, and $\mathrm{Pb}$ has a negative effect on the yield of oats (Wyszkowska et al. 2006). These metals have a negative effect on soil fertility, water quality, and could be transported to human food chain causing great health risk (Elnazer et al. 2015; Salman et al. 2017)

The high average concentration of $\mathrm{Zr}, \mathrm{Zn}, \mathrm{Cr}, \mathrm{Ni}, \mathrm{Pb}$, $\mathrm{Co}, \mathrm{Cu}$, As, and $\mathrm{Cd}$ (Table 2) indicated an anthropogenic input. $\mathrm{Zr}, \mathrm{Zn}, \mathrm{Cr}, \mathrm{Ni}, \mathrm{Pb}, \mathrm{Co}$, and $\mathrm{Cu}$ are strongly positively correlated with silt, clay fractions, and iron (Table 5). Thus, they may be adsorbed with the clay minerals and/or iron oxy-hydroxides minerals. As, $\mathrm{Pb}$, and $\mathrm{Cd}$ are positively correlated with $\mathrm{P}_{2} \mathrm{O}_{5}$ (Table 5), which indicated that the phosphatic fertilizer plays a vital role in the pollution of soil with these metals. Also, these elements are positively correlated with each other; consequently, these may be indicating that they concentrated under the same environmental conditions.

Generally, the cultivated soil is affected mainly by (a) agricultural anthropogenic input, such as fertilizers, pesticides, green manure, wastewater irrigation, etc., and (b) atmospheric deposition.

Sample numbers (1, south Mangabad fertilizer factory), (2, 10, 11, and 14, north El-Waleidia electricity station), (12 and 13, west El-Madabk Sewage Station), and (16 south Seed Pharmaceutical factory) represented the highest concentrations in $\mathrm{As}, \mathrm{Zn}$, and $\mathrm{Pb}$ (Table 2).

Also, sample numbers (1) in north, 12 and 13 in south, and 16 nearby the Seed Pharmaceutical factory represented high concentration in all the heavy and toxic elements (Table 2). In addition, samples number 3 and 4 
Table 5 Correlation matrix of the heavy metals in the studied agricultural soils

\begin{tabular}{|c|c|c|c|c|c|c|c|c|c|c|c|c|c|c|c|c|c|}
\hline & Sand & Silt & Clay & $\mathrm{CaCO}_{3} \%$ & $\mathrm{Fe}_{2} \mathrm{O}_{3}$ & $\mathrm{P}_{2} \mathrm{O}_{5}$ & $\mathrm{Fe}$ & $\mathrm{Mn}$ & $\mathrm{Zn}$ & $\mathrm{Zr}$ & As & $\mathrm{Pb}$ & $\mathrm{Cd}$ & $\mathrm{Co}$ & $\mathrm{Cr}$ & $\mathrm{Cu}$ & $\mathrm{Ni}$ \\
\hline $\mathrm{Fe}$ & $-0.95^{* *}$ & $0.96^{* *}$ & $0.79^{* *}$ & 0.13 & $.78^{* *}$ & -0.14 & 1 & & & & & & & & & & \\
\hline $\mathrm{Mn}$ & $-0.88^{* *}$ & $0.90^{* *}$ & $0.73^{* *}$ & 0.06 & $.65^{* *}$ & -0.24 & $0.90^{* *}$ & 1 & & & & & & & & & \\
\hline $\mathrm{Zn}$ & $-0.70^{* *}$ & $0.73^{* *}$ & 0.50 & 0.09 & 0.16 & 0.28 & $0.56^{*}$ & $.50^{*}$ & 1 & & & & & & & & \\
\hline $\mathrm{Zr}$ & $-0.58^{*}$ & $0.56^{*}$ & $0.53^{*}$ & 0.21 & $.66^{* *}$ & -0.18 & $0.64^{* *}$ & $.54^{*}$ & 0.32 & 1 & & & & & & & \\
\hline As & 0.07 & -0.11 & 0.07 & -0.44 & -0.33 & 0.29 & -0.19 & -0.12 & 0.18 & -0.19 & 1 & & & & & & \\
\hline $\mathrm{Pb}$ & -0.12 & 0.13 & 0.04 & 0.01 & -0.19 & 0.21 & -0.09 & -0.04 & $.61^{*}$ & 0.03 & 0.18 & 1 & & & & & \\
\hline $\mathrm{Cd}$ & -0.37 & 0.31 & 0.46 & 0.18 & $.58^{*}$ & 0.30 & 0.44 & 0.34 & 0.04 & $0.63^{* *}$ & -0.11 & -0.16 & 1 & & & & \\
\hline Co & $-0.88^{* *}$ & $0.90^{* *}$ & $0.70^{* *}$ & 0.06 & $.84^{* *}$ & -0.19 & $0.93^{* *}$ & $0.85^{* *}$ & $0.45^{*}$ & $0.56^{*}$ & -0.29 & 0.05 & 0.35 & 1 & & & \\
\hline $\mathrm{Cr}$ & $-0.75^{* *}$ & $0.73^{* *}$ & $0.71^{* *}$ & 0.23 & $.81^{* *}$ & -0.13 & $0.85^{* *}$ & $0.72^{* *}$ & 0.24 & $0.75^{* *}$ & -0.21 & -0.19 & $.74^{* *}$ & $.76^{* *}$ & 1 & & \\
\hline $\mathrm{Cu}$ & $-0.87^{* *}$ & $0.92^{* *}$ & $0.60^{*}$ & 0.12 & $.66^{* *}$ & -0.09 & $0.87^{* *}$ & $0.81^{* *}$ & $.74^{* *}$ & $.51^{*}$ & -0.08 & 0.31 & 0.21 & $.91^{* *}$ & $.62^{* *}$ & 1 & \\
\hline $\mathrm{Ni}$ & $-0.50^{*}$ & $0.53^{*}$ & 0.31 & 0.12 & 0.24 & 0.12 & 0.45 & 0.40 & $.74^{* *}$ & 0.28 & 0.01 & 0.50 & 0.05 & 0.48 & 0.20 & $.64^{* *}$ & 1 \\
\hline
\end{tabular}

** Correlation is significant at the 0.01 level (two-tailed). * Correlation is significant at the 0.05 level (two-tailed)

recorded high content in $\mathrm{Mn}, \mathrm{Zn}, \mathrm{Zr}, \mathrm{As}, \mathrm{Pd}, \mathrm{Cd}, \mathrm{Co}, \mathrm{Cu}$, and $\mathrm{Ni}$ which results from the Mangabad fertilizer factory (Table 2). Sample No. (1) recorded the highest percentage of Cd (2.4 ppm), indicating the worst effect of Mangabad fertilizer factory on the soil of cultivated land.

The significant positive correlation (Table 5) is observed between $\mathrm{Fe}$ versus $\mathrm{Zr}, \mathrm{Co}, \mathrm{Cr}, \mathrm{Cu}$, and $\mathrm{Zn}(r=0.64,0.93$, $0.85,0.87$, and 0.56 , respectively). This possibly indicates the adsorption of these elements on Fe-oxy-hydroxide or Fe-rich clay minerals (such as vermiculite mineral, which is detected by the mineralogical studies with Abou El-Anwar et al. (2018). Also, the positive relation between $\mathrm{P}_{2} \mathrm{O}_{5}$ versus $\mathrm{As}, \mathrm{Pb}, \mathrm{Cd}$, and $\mathrm{Zn}(r=0.29,0.21$, 0.30 , and 0.28 , respectively (Table 5 ) revealed that these toxic elements are mostly related to the Mangabad fertilizer factory.

\section{Conclusions}

The mean concentrations of the major elements in these soil decrease from $\mathrm{Si}>>\mathrm{Al}>\mathrm{CaCO}_{3}>\mathrm{Fe}>\mathrm{Ca}>\mathrm{Mg}>$ $\mathrm{OM}>\mathrm{Ti}>\mathrm{K}>\mathrm{Na}>\mathrm{P}>\mathrm{Mn}>\mathrm{S}$. The concentrations of $\mathrm{K}$, $\mathrm{Fe}, \mathrm{Ti}$, and $\mathrm{Mg}$ are primarily related to $\mathrm{Al}$, and as such, these elements are dominantly controlled by clay minerals and/or by minerals associated with clays during sedimentation.

The high concentration of $\mathrm{Zr}, \mathrm{Zn}, \mathrm{Cr}, \mathrm{Ni}, \mathrm{Pb}, \mathrm{Co}, \mathrm{Cu}$, $\mathrm{As}$, and $\mathrm{Cd}$ indicated their anthropogenic input. $\mathrm{As}, \mathrm{Pb}$, and $\mathrm{Cd}$ could be mainly coming from the application of phosphatic fertilizer. The industrial activities (Seed Pharmaceutical and Mangabad fertilizer factories) contributed greatly in the pollution of soil with heavy metals.

The authors mentioned to some recommendations which can decrease the effect of the pollutions: (1) create a barrier of suitable size between the wastewater disposal sites and populated or farming areas where contamination represented a problem, (2) augment the awareness of the government about these problems and to help the people to understand the potential extent of such pollutions on their health and plants, and (3) must treat the wastewater to diminish the possibility of contamination.

Acknowledgements

The authors would like to thank The Geological Sciences Dept., National Research Centre for facilitates during this work.

Funding

NRC internal project ID: 11080101.

Availability of data and materials

Not applicable.

Authors' contributions

All authors contributed equally in all article steps. All authors read and approved the final manuscript.

Authors' information

Not applicable.

Ethics approval and consent to participate

Accepted.

Consent for publication

Accepted.

\section{Competing interests}

The authors declare that they have no competing interests.

\section{Publisher's Note}

Springer Nature remains neutral with regard to jurisdictional claims in published maps and institutional affiliations.

Received: 3 January 2019 Accepted: 27 February 2019

Published online: 12 March 2019

\section{References}

Abou El-Anwar EA, Mekky HS, Salman SA, Elnazer AA, Abdel Wahab W, Asmoay AS (2018) Mineraological and petrographical studies of Agriculture Soil, Assiut Governorate, Egypt. Bull NRC (Under Published)

Abou El-Anwar EA, Samy YM (2013) Clay mineralogy and geochemical characterization of some Quaternary sediments on Giza-Fayium District, Western Nile Valley, Egypt: relationships to weathering and provenance. J Appl Sci Res 9(8):4765-4780

Al Naggar Y, Naiem E, Mona M, Giesy JP, Seif A (2014) Metals in agricultural soils and plants in Egypt. Toxicol Environ Chem 96(5):730-742 
Al-Gamal AGI (2011) Comparative geological and mineralogical studies on some Egyptian bentonitic clay deposits. M.Sc. Thesis. Fac. Sci. Al-Azhar Univ, Egypt

Al-Marsoumi AMH, Kadhum MJ, Kadhum SK (2008) Some mechanical properties of sandy gypseferous soils in Rumaila - Khor Al-Zubair area, southern Iraq. Marina Mesopotamica 23(2):333-347

Asmoay ASA (2017) Hydrogeochemical studies on the water resources and soil characteristics in the Western Bank of the River Nile between Abu Qurqas and Dayr Mawas, El Minya Governorate, Egypt. Ph.D. thesis. Fac. Sci. Al-Azhar Univ, Egypt, p 255

Bekir RK (1997) The Nile Valley soil, types and clay minerals characteristics, Sohag, Egypt. Egypt Mineral 9:251-264

Choudhary OP, Josan AS, Bajwa MS, Kapur ML (2004) Effect of sustained sodic and saline-sodic irrigation and application of gypsum and farmyard manure on yield and quality of sugarcane under semi-arid conditions. Field Crop Res 87:103-116

Conoco. Geologic map of Egypt. Egyptian General Authority for Petroleum. Scale (1:500,000), NG 36 NW Asyut. 1987

Darwish MAG, Pollmann H (2015) Trace elements assessment in agricultural and desert soils of Aswan area, south Egypt: geochemical characteristics and environmental impacts. J Afr Earth Sci 112:358-373

Elgharably A, Abdel Mageed A, Elgharably G (2014) Status of heavy metals in soils of Assiut as affected by the long-term use of sewage water in crop irrigation: case study. Egypt J Soil Sci 54(4):289-304

Elnazer AA, Salman SA, Seleem EM, Abu El Ella EM (2015) Assessment of some heavy metals pollution and bioavailability in roadside soil of AlexandriaMarsa Matruh Highway, Egypt. Intern J Ecol:7. https://doi.org/10.1155/2015/ 689420 Article ID 689420

El-Sayed EA, Hegazy MNA (1993) Total contents and extractable amounts of Cd, $\mathrm{Co}, \mathrm{Cr}$ and $\mathrm{Ni}$ in some soils of El-Fayoum Govern. Egypt. Fayoum. J Agric Res Develop 7:46-56

Galinha C, Freitas MC, Pacheco AMG (2010) Enrichment factors and transfer coefficients from soil to rye plants by INAA. J Radioanal Nucl Chem 286:583-589

Herrero J, Porta J (2000) The terminology and the concepts of gypsum-rich soils. Geoderma 96:47-61

Hussein AN, Omar H, Jamaludin S (2004) Slope assessment and management. In: Huat BBK, Gue SS, Ali FH (eds) Tropical Residual Soils Engineering. Balkema, Taylor and Francis, UK, pp 103-120

Ji W, Yang T, Ma S, Ni W (2012) Heavy metal pollution of soils in the site of a retired paint and ink factory. Energy Procedia 16:21-26

Kabata-Pendias A, Mukherjee AB (2007) Trace elements from soil to human. Springer Berlin Heidelberg, New York, p 550

Karim Z, Qureshi BA, Mumtaz M (2015) Geochemical baseline determination and pollution assessment of heavy metals in urban soils of Karachi, Pakistan. Ecol Indicat 48:358-364

Khalifa MA, Abu El Gar MS, Helal S, Hussein AW (2004) Depositional history of the Lower Eocene drowned carbonate platform (Drunka Formation), west of Assiut and El Minia stretch, Western Desert, Egypt. In: The $7^{\text {Th }}$ Intern. Conf. Geol. Arab World, Cairo Univ., pp 233-254

Liu D, Yang Q, Tang D, Kang X, Huang W (2001) Geochemistry of sulfur and elements in coals from the Antaibao surface mine, Pingshuo, Shanxi Province, China. Intern J Coal Geol 46:51-64

Lu Y, Song S, Wang R, Liu Z, Meng J, Sweetman AJ, Jenkins A, Ferrier RC, Li H, Luo W, Wang T (2015) Impacts of soil and water pollution on food safety and health risks in China. Environ Intern 77:5-15

Massas I, Ehaliotis C, Gerontidis S, Sarris E (2009) Elevated heavy metal concentrations in top soils of an Aegean Islan town (Greece): Total and available forms, origin and distribution. Environ Monit Assess 151(1):105-116

Melegy AA, El-Agami NL (2004) Factors controlling the chemistry and mineralogy of selected soil types of the Czech Republic and Egypt. Bull Geosci 79(1):71-79

Mohamed TA, Mohamed MA, Rabeiy R, Ghandour MA (2013) A study of heavy metals in the dust fall around Assiut fertilizer plant. J Environ Prot 4:1488-1494

Mohamed WS, Ismail EA, Zaki R, Kamel A (2015) Regional assessment of heavy metals pollution in irrigated soils, west El Minia district, Egypt. Egypt J Geol 59:101-112

Omer AA (1996) Geological, mineralogical and geochemical studies on the Neogene and Quaternary Nile basin deposits, Qena-Assiut stretch, Egypt. Ph. D. thesis, Geol. Dept. Fac. Sci., Sohag, South Valley Univ, p 320

Osman HZ (1980) Geological studies on the area to the northwest of Assiut. M. Sc. thesis. Fac. Sci., Assiut Univ, Assiut, p 276

Querol X, Finkelman RB, Alastuey A, Huerta A, Palmer CA, Mroczkowski S, Kolker A, Chenery SNR, Robinson JJ, Lopez-Soler A (1998) Quantitative determination of modes of occurrence of major, minor and trace elements in coal: a comparison of results from different methods. In: Proceedings of the AIE $8^{\text {th }}$ Australian Coal Conference, pp 51-56

Rabie FH, Abd El-Sabour MF (1999) Studies on Fe, Mn, Ni and Pb load on soil and its enrichment factor ratios in different soil grain size fractions as an indicator for soil pollutin. Ass Univ Bull Environ Res 2(2):11-22

Razouki SS, Kuttah DK (2006) Predicting long-term soaked CBR of gypsiferous subgrade soils. Proc Inst Civ Eng Transport 159(3):135-140

Rudnick RL, Gao S (2014) Composition of the continental crust. Treat Geochem 4:1-51

Said R (1962) The geology of Egypt. Elsevier Publishing Company, AmsterdamNew York

Said R (1981) The geological evolution of the River Nile. Springer Verlag, New York, Heidelbeirg, Berlin, p 151

Salman SA (2008) Study of some environmental impacts on Maghara Coal Mine area. M.Sc. Thesis, Fac. Sci., Al-Azhar Univ., Egypt

Salman SA (2013) Geochemical and environmental studies on the territories west River Nile, Sohag Governorate Egypt. Ph.D. Thesis. Fac. Sci., Al-Azhar Uni, Egypt

Salman SA, Elnazer AA, El Nazer HA (2017) Integrated mass balance of some heavy metals fluxes in Yaakob village, south Sohag, Egypt. Int J Environ Sci Technol 14:1011-1018

Samuding K, Abustan I, Abdul Rahman MT, Isa MH (2009) Distribution of heavy metals profile in groundwater system at solid waste disposal site. Eur J Sci Res 1:58-66

Van der Veer G (2006) Geochemical soil survey of the Netherlands: Atlas of major and trace elements in topsoil and parent material; assessment of natural and anthropogenic enrichment factors. Fac Earth Sci, Utrecht Univ, Netherlands

Wyszkowska J, Kucharski J, Lajszner W (2006) The effects of copper on soil biochemical properties and its interaction with other heavy metals. Pol J Environ Stud 15(6):927-934

\section{Submit your manuscript to a SpringerOpen ${ }^{\circ}$ journal and benefit from:}

- Convenient online submission

Rigorous peer review

- Open access: articles freely available online

- High visibility within the field

- Retaining the copyright to your article

Submit your next manuscript at $>$ springeropen.com 